\title{
A specific and unusual nuclear localization signal in the DNA binding domain of the Rev-erb orphan receptors
}

\author{
S Chopin-Delannoy, S Thénot ${ }^{1}$, F Delaunay ${ }^{1}$, E Buisine, A Begue, \\ M Duterque-Coquillaud and V Laudet ${ }^{1}$ \\ Institut de Biologie de Lille, CNRS UMR 8526, Institut Pasteur de Lille, 1 rue Calmette, 59021 Lille cedex, France \\ ${ }^{1}$ Laboratoire de Biologie Moléculaire et Cellulaire, CNRS UMR 5665, Ecole Normale Supérieure de Lyon, 46 allée d'Italie, 69364 Lyon cedex, France \\ F Delaunay is now at Université de Nice, CNRS UMR 6078, Chemin du Lazaret, Villefranche-sur-mer, France
}

(Requests for offprints should be addressed to V Laudet, Laboratoire de Biologie Moléculaire et Cellulaire, CNRS UMR 5665, Ecole Normale Supérieure de Lyon, 46 allée d'Italie, 69364 Lyon cedex, France; Email: Vincent.Laudet@ens-lyon.fr)

\begin{abstract}
The orphan receptors Rev-erb $\alpha$ and Rev-erb $\beta$ are members of the nuclear receptors superfamily and act as transcriptional repressors. Rev-erb $\alpha$ is expressed with a robust circadian rhythm and is involved in liver metabolism through repression of the ApoA1 gene, but no role has been yet defined for Rev-erb $\beta$. To gain better understanding of their function and mode of action, we characterized the proteins encoded by these two genes. Both Rev-erb $\alpha$ and Rev-erb $\beta$ proteins were nuclear when transiently transfected in COS-1 cells. The major nuclear location signal (NLS) of Rev-erbo is in the amino-terminal region of the protein. Fusion of green fluorescent protein (GFP) to the amino terminus of Rev-erbo deletion mutants showed that the NLS is located whithin a 53 amino acid segment of the DNA binding domain (DBD). The homologous region of Rev-erb $\beta$ fused to GFP also targeted the fusion protein to the nucleus, suggesting that the location of this NLS is conserved among all the Rev-erb group members. Interestingly, members of the phylogenetically closest nuclear orphan receptor group (ROR), which exhibit $58 \%$ amino acid identity with Rev-erb in the DBD, do not have their NLS located whithin the DBD. GFP/DBD.ROR $\alpha$ or GFP/DBD.ROR $\beta$ remained cytoplasmic, in contrast to GFP/DBD.Rev-erb fusion proteins. Alignment of human Rev-erb and ROR DBD amino acid sequences predicted that the two basic residues, K167 and R168, located just upstream from the second zinc finger, could play a critical part in the nuclear localization of Rev-erb proteins. Substitution of these two residues with those found in ROR, in the GFP/DBD.Rev-erb context, resulted in cytoplasmic proteins. In contrast, the reverse mutation of the GFP/DBD.ROR $\alpha$ towards the Rev-erb $\alpha$ residues targeted the fusion protein to the nucleus. Our data demonstrate that Rev-erb proteins contain a functional NLS in the DBD. Its location is unusual within the nuclear receptor superfamily and suggests that Rev-erb orphan receptors control their intracellular localization via a mechanism different from that of other nuclear receptors.
\end{abstract}

Journal of Molecular Endocrinology (2003) 30, 197-211

\section{Introduction}

Nuclear hormone receptors have an important role in cellular regulation, providing a direct link between extracellular hormonal signals and transcriptional responses (Laudet \& Gronemeyer 2002). These molecules are ligand-activated transcription factors that regulate the expression of target genes by binding to specific cis acting sequences
(Mangelsdorf et al. 1995). The superfamily includes receptors for steroid hormones, retinoic acid, thyroid hormone, vitamin $\mathrm{D}$ and fatty acids. In most cases, nuclear receptors are inducible transcriptional activators, which actively repress transcription of their target genes in the absence of hormone and activate transcription upon ligand binding. All nuclear receptors share the same overall protein organization with several 
independent functional domains. In the N-terminal domain (A/B domain), a hormone-independent transactivation function (AF1 region) has been identified in many receptors such as thyroid hormone receptors (TR, NR1A in the official nomenclature, see Nuclear Receptors Nomenclature Committee 1999) or steroid receptors (NR3C) (Laudet \& Gronemeyer 2002). Immediately downstream, the highly conserved $\mathrm{C}$ domain, a sequence signature of the superfamily, is responsible for both specific DNA binding and dimerization. Although also participating to some extent in the DNA binding function, the $\mathrm{D}$ domain is mainly considered as a flexible hinge region between the DNA binding domain (DBD) and the C-terminal ligand-binding domain (LBD; $\mathrm{E}$ domain). The LBD contains the hormone binding pocket, the major dimerization interface and a hormonedependent transactivation function, called AF2. Like the $\mathrm{C}$ domain, the $\mathrm{E}$ domain is evolutionarily conserved among the receptors (Laudet 1997). On the basis of this domain organization, and significant sequence conservation, a large number of so-called orphan receptors have been characterized (Enmark \& Gustafsson 1996). These members of the superfamily contain the same domains as the liganded receptors, but the identity of their ligand is still unknown. In fact, it is unclear whether these receptors are regulated by a ligand still to be identified or whether they are true orphans that are regulated by mechanisms other than ligand binding (Escriva et al. 2000).

The intracellular localization of nuclear receptors is the result of a dynamic equilibrium of cytoplasmic-nuclear shuttling as demonstrated for the progesterone receptor (PR, NR3C3) and the glucocorticoid receptor (GR, NR3G1) (GuiochonMantel et al. 1991, Madan \& DeFranco 1993). Nuclear translocation of cytoplasmic receptors is due to the presence of short sequences rich in basic amino acids, called nuclear localization signals (NLSs). NLSs are most often located in the junction between the $\mathrm{C}$ and $\mathrm{D}$ domains, in the $\mathrm{D}$ domain or in the $\mathrm{E}$ domain (Laudet \& Gronemeyer 2002). NLSs located in the $\mathrm{E}$ domain are liganddependent but their precise location and sequence remain unknown. Studies on the subcellular localization of unliganded receptors indicate three categories: exclusively cytoplasmic receptors like GR and androgen receptor (AR, NR3C4) (Htun et al. 1996, Georget et al. 1998), both cytoplasmic and nuclear receptors like mineralocorticoid receptor (MR, NR3C2) and TR $\beta$ (NR1A2) (Fejes-Toth et al. 1998, Zhu et al. 1998), and exclusively nuclear receptors like oestrogen receptor $\alpha(\mathrm{ER} \alpha, \mathrm{NR} 3 \mathrm{Al})$ and $\mathrm{PR}$ (GuiochonMantel et al. 1989, Lim et al. 1999), although in some cases this issue remains controversial. All receptors located in the cytoplasm in the unliganded (apo-) form translocate into the nucleus upon ligand binding (Htun et al. 1996, Fejes-Toth et al. 1998, Georget et al. 1998, Zhu et al. 1998, Lim et al. 1999). Unliganded receptors that are located in cytoplasm, such as GR, AR and TR $\beta$, have in common the position of their NLS in the T and A boxes just downstream of the C domain (Picard \& Yamamoto 1987, Zhou et al. 1994, Zhu et al. 1998). These boxes have been shown to play an important part in DNA binding and dimer formation (Laudet \& Gronemeyer 2002). It is believed that, in such a position, the NLS is exposed by the conformational changes induced in the LBD upon ligand binding, and becomes accessible to the nuclear translocation machinery. In contrast, ER $\alpha$ and PR, apo-forms located in the nucleus, have three proto-NLSs located in the $\mathrm{C}$ and $\mathrm{D}$ domains (Guiochon-Mantel et al. 1989, Ylikomi et al. 1992). These NLSs function cooperatively, because the association between two or three proto-NLSs is required to translocate the receptor to the nucleus.

The Rev-erb group of orphan receptors contains two mammalian members, Rev-erb $\alpha$ (NR1D1) and Rev-erb $\beta$ (NR1D2), and one from Drosophila, the ecdysone-regulated gene E75 (NR1D3) (Lazar et al. 1989, Miyajima et al. 1989, Segraves \& Hogness 1990, Laudet et al. 1991, Bonnelye et al. 1994, Dumas et al. 1994, Enmark et al. 1994, Retnakaran et al. 1994). The founding member of this group, Rev-erba, was discovered as a gene transcribed on the non-coding strand of the c-erbA-1 protooncogene that encodes TR $\alpha$ (NR1A1) (Lazar et al. 1989, Miyajima et al. 1989, Laudet et al. 1991). Rev-erb receptors are closely related to the ROR (NR1F) group of nuclear receptors, which contains three genes, $\alpha, \beta$ and $\gamma$ (NR1F1-3), and a unique homologue in Drosophila, called DHR3 (NR1F4) (Koelle et al. 1992, Carlberg et al. 1994, Giguere et al. 1994, Hirose et al. 1994). ROR $\alpha$ and Rev-erba share 58\% and $37 \%$ identical amino acids in the $\mathrm{C}$ and $\mathrm{E}$ domains respectively. Rev-erbs have no known ligand, lack the AF2-activating domain (AF2-AD) region that is 
necessary for coactivator binding, bind to DNA as monomers or homodimers, and constitutively repress transcription when bound on their responsive element, known as RevRE (recognized by the monomeric form) or RevDR2 (bound by the homodimer) (Harding \& Lazar 1995, Adelmant et al. 1996, Renaud et al. 2000). In contrast to Rev-erbs, ROR orphan receptors act as constitutive transcriptional activators in the absence of exogenously added ligand through monomeric DNA response elements that are extremely similar to the RevRE. In a given cell, the amount of activity emanating from a RevRE is the result of a balance between activation by ROR and repression by Rev-erb proteins. Little is known about Rev-erb functions in vivo. Rev-erba gene expression is induced during adipocyte differentiation, is downregulated during muscle differentiation, and is under circadian regulation in adult rat liver and during development in the zebrafish (Chawla \& Lazar 1993, Balsalobre et al. 1998, Downes et al. 1995, Delaunay et al. 2000). Rev-erba represses transcription of the apolipoprotein Al (ApoAl) and hydratase dehydrogenase genes, suggesting a role of this orphan receptor in metabolic control (Vu-Dac et al. 1998, Kassam et al. 1999). In accordance with this notion, we have shown that fibrates, commonly used hypolipidaemic drugs, decrease ApoAl concentrations through induction of Rev-erba gene expression in liver (Gervois et al. 1999).

To date, most studies dealing with NLS in nuclear receptors have been devoted to liganded receptors, and there are only a very few reports on NLS location in orphan receptors (Hager et al. 2000, Laudet \& Gronemeyer 2002). In an attempt to gain better understanding of the mode of action of Rev-erb gene products, we decided to characterize the proteins encoded by these genes. Given a possible role in circadian rhythms, we first concentrated on the location of the Rev-erb NLS, because it has been shown that nuclear entry of proteins that are part of the circadian oscillator is tightly regulated (Lee et al. 2001). To analyse the subcellular distribution of Rev-erb proteins, we generated polyclonal antibodies that were able specifically to recognize Rev-erb $\alpha$ or Rev-erb $\beta$. Using transient transfection assays and green fluorescent protein (GFP) fusion proteins, we mapped Rev-erb NLS within the DBD and we showed that two basic amino acids located just upstream of the second zinc finger have a critical role in this NLS. Surprisingly, this NLS is not conserved in the closely related ROR orphan receptors.

\section{Materials and methods}

\section{Expression of Rev-erb fragment in bacteria, and generation of rabbit sera}

The appropriate fragments were obtained from Rev-erb $\alpha$ and Rev-erb $\beta$ encoding cDNAs as templates in polymerase chain reaction (PCR) experiments using oligonucleotides containing either a BamHI restriction site $\left(5^{\prime}\right.$ oligo) or a HindIII site (3' oligo). These fragments were introduced in a pLC24-derived vector linearized with BamHI and HindIII. The sub-cloning resulted in the in-frame fusion of the desired sequence to the first 99 amino acids of the RNA polymerase of phage MS2.

The oligonucleotides used to amplify the region of the chicken (ck) Rev-erb $\beta$ DBD were as follows: 5' primer: 5'-TAG GGA TCG CAA TAG AAA CAG ATG CCA G; 3' primer: 5'-ATC AAG CTT ACA TGG CAC TCT GCA TTT C. This fragment contains the region coding for 43 amino acids from position 127 to position 170 of the ckRev-erb $\beta$ protein. As this region is highly conserved between Rev-erb proteins, it generated a serum able to recognize both Rev-erb $\alpha$ and $\beta$ (hence its name, AB43). The oligonucleotides used to amplify the region of human (h) Rev-erba LBD in order to generate a Rev-erb $\alpha$-specific serum (called A83) were as follows: 5' primer: 5'-TAG GGA TCG CGG GCA GGG CAA CTC AAA G; 3' primer: 5'-ATG AAG CTT AGA CGT TGA ACA ACG AAG C. This fragment contains the region coding for 83 amino acids of the LBD of hRev-erb $\alpha$ from position 407 to position 490. The oligonucleotides used to amplify the region of ckRev-erb $\beta$ LBD in order to generate a Rev-erb $\beta$ specific serum (called B81) were as follows: 5' primer: 5'-TAG GGA TCG CAA CAG TGG AGG AAG AAT G; 3' primer: 5'-ATG AAG CTT ATG CAT CAA ACA AAG ATG C. This fragment contains the region coding for 81 amino acids of the LBD of ckRev-erb $\beta$ from position 345 to position 426. The A83 and B81 peptides correspond to homologous regions in the two proteins and their conservation across species made it possible to obtain isoform-specific serum that can 
recognize either Rev-erb $\alpha$ or Rev-erb $\beta$ proteins from several species.

For expression, plasmids grown in LE392( $\lambda$ ) were transferred into an Escherichia coli host (SG4044) that has a temperature-sensitive repressor of the $p \mathrm{~L}$ promoter. Cultures of exponentially growing bacteria carrying the desired vector were incubated at $42{ }^{\circ} \mathrm{C}$ for $3 \mathrm{~h}$. Bacterial pellets were washed twice, boiled in sample buffer, and electrophoresed on an SDS-15\% polyacrylamide gel. Proteins were visualized by staining with Coomassie brilliant blue and cut from the gel. Rabbit antisera were prepared from these proteins.

The preimmune sera were obtained before immunization. The adsorbed sera were adsorbed on the fusion protein against which they were raised. The specific A83 serum, A83 Spe, corresponds to the A83 serum adsorbed against the fusion protein MS2-B81 because, as indicated above, the A83 and B81 peptides were derived from homologous regions of the two proteins. In the same way, the specific B81 serum, B81 Spe, corresponds to the B81 serum adsorbed against the fusion protein MS2-A83.

\section{Plasmids for immunofluorescence}

The appropriate fragments used for immunofluorescence were obtained from pSG5 hReverba expression vector by PCR experiments using oligonucleotides containing a $5^{\prime}$ HindIII restriction site and start codon, and a $3^{\prime}$ BamHI restriction site and stop codon. The expected bands were subjected to HindIII-BamHI restriction enzyme digestion and inserted between the HindIII and BamHI sites of pSG5. Oligonucleotide sequences are available from author $\mathrm{V} \mathrm{L}$ upon request.

\section{GFP chimeras}

The appropriate fragments used to construct the GFP chimeras were obtained from pSG5 hReverb $\alpha$-, pSG5 ckRev-erb $\beta$-, pCMXhROR $\alpha$ - and pCMXROR $\beta$-encoding cDNAs by PGR experiments using oligonucleotides containing a $5^{\prime}$ HindIII restriction site and a $3^{\prime}$ BamHI restriction site. The expected bands were subjected to HindIII-BamHI digestion and inserted between the HindIII and BamHI sites of pEGFP-C1 (Clontech). The sub-cloning resulted in the in-frame fusion of the desired sequence to the C-terminal part of the first 238 amino acids of the GFP. All GFP constructs were checked by sequencing. Oligonucleotide sequences are available from author $\mathrm{V} \mathrm{L}$ upon request.

\section{In vitro translation and immunoprecipitation}

Methionine-labelled hRev-erb $\alpha$ and ckRev-erb $\beta$ proteins were synthesized in cell-free conditions using the rabbit reticulocyte lysate system (Promega) according to the manufacturer's recommendations. The synthesized proteins were tested on $10 \%$ SDS-polyacrylamide gel or were incubated with polyclonal antibody overnight at $4{ }^{\circ} \mathrm{C}$ in radioimmunoassay modified buffer (RIPA) buffer

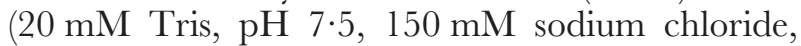
$2 \mathrm{mM}$ EDTA, 1\% (wt/vol) sodium deoxycholate, $1 \%$ (vol/vol) Triton X-100, 0.25\% (wt/vol) SDS). Immune complexes were collected using protein A-sepharose (Pharmacia) and washed six times in RIPA buffer. Protein complexes were separated on $10 \%$ SDS-polyacrylamide gels. Gels were dried and exposed to Hyper film (Amersham).

\section{Immunofluorescence and GFP chimera analysis}

COS-1 cells were maintained in Dulbecco's modified Eagle's medium supplemented with 10\% fetal calf serum.

Plasmid DNAs were transiently transfected in cells using PEI (Euromedex, Mundolsheim, France) according to the supplier's instructions. COS-1 cells transfected with the relevant pSG5 construct were fixed, $48 \mathrm{~h}$ after transfection, in $4 \%$ paraformaldehyde in PBS for $20 \mathrm{~min}$. The cells were permeabilized with $0 \cdot 15 \%$ Triton X-100 in PBS for 2 min. After treatment with $1 \%$ ethanolamine in PBS for $20 \mathrm{~min}$ at $4{ }^{\circ} \mathrm{C}$, the sera were diluted at $1 / 100$ in $0.5 \%$ bovine serum albumin and incubated for $1 \mathrm{~h}$ at $37^{\circ} \mathrm{C}$ with the fixed cells. The anti-Rev-erb immunoreactive proteins were detected with fluorescein isothiocyanate goat antirabbit immunoglobulins (Dako, Trappes, France) secondary reagent. For localization of GFP fusion proteins, transfected COS-1 cells were fixed $48 \mathrm{~h}$ after the transfection in 2\% paraformaldehyde, $0 \cdot 2 \%$ glutaraldehyde in PBS. The cells were observed using an epifluorescence microscope (Axiovert $135 \mathrm{TV}$, Zeiss) with specific filters. In 
each experiment, 300 cells were counted, and each experiment was performed three times.

\section{Results}

\section{Production of polyclonal antibodies against Rev-erb proteins}

To study the Rev-erb proteins, we decided to produce polyclonal antibodies with different specificities: one that specifically recognizes Rev-erb $\alpha$ proteins from several species, another that specifically recognizes Rev-erb $\beta$ proteins, and one that may recognize both Rev-erb $\alpha$ and Rev-erb $\beta$. With this aim, we generated several fusion proteins containing various regions of the Rev-erb proteins. We took advantage of the fact that Rev-erb $\alpha$ and Rev-erb $\beta$ proteins share $97 \%$ identity in their DBD, and $68 \%$ in their LBD. To obtain a serum able to recognize both Rev-erb $\alpha$ and $\operatorname{Rev}-\operatorname{erb} \beta$, we used a 43 amino acid fragment located in the C-terminal part of the Rev-erb $\beta$ DBD (Fig. 1a), which is highly conserved between both paralogous gene products. Using this fragment, we generated the AB43 serum in order to label both Rev-erb $\alpha$ and Rev-erb $\beta$. To obtain a Rev-erb $\alpha$-specific serum, called A83, we targeted an 83 amino acid region of the LBD (Fig. 1a), which is different from the corresponding Rev-erb $\beta$ region, but well conserved among the various known Rev-erb $\alpha$ proteins. The homologous region of Rev-erb $\beta$ was used to generate the B81 serum in order to recognize the Rev-erb $\beta$ protein specifically (Fig. 1a).

We tested the ability of the AB43 serum specifically to recognize Rev-erb proteins using whole $\left[{ }^{35} \mathrm{~S}\right]$ methionine-labelled hRev-erb $\alpha$ or ckRev-erb $\beta$ expressed in reticulocyte lysates (Fig. $1 b$, lanes 13 and 14: labelled proteins produced by the reticulocyte lysate system). Using immunoprecipitation experiments, we obtained proteins of the expected size $(68 \mathrm{kDa}$ and $60 \mathrm{kDa}$ for Rev-erb $\alpha$ and Rev-erb $\beta$ respectively; lanes 3 and 4 ) that were not recognized by the preimmune $(\mathrm{Pi}$; lanes 1 and 2) or the adsorbed sera (Ads, lanes 5 and 6). We verified that this serum was unable to cross-react with the closely related $\operatorname{ROR} \alpha$ and $\operatorname{ROR} \beta$ (data not shown). We conclude from these experiments that the $\mathrm{AB} 43$ antibody is able to recognize both Rev-erb $\alpha$ and Rev-erb $\beta$.

Using the same approach, we characterized the specific sera A83 (Fig. 1b) and B81 (not shown). (a)
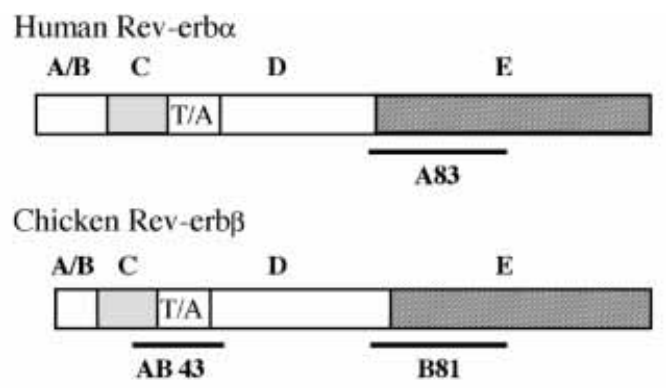

(b)
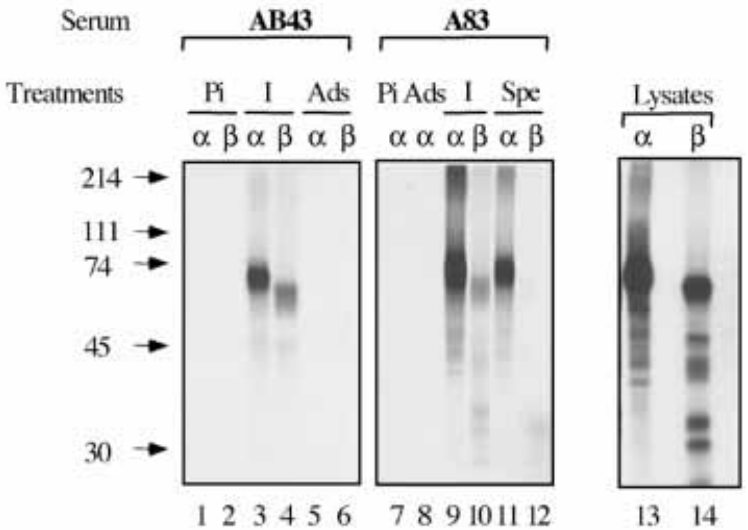

Figure 1 Generation of specific antibodies directed against the Rev-erb proteins. (a) Structure of the Rev-erb $\alpha$ and Rev-erb $\beta$ proteins. The localization of the fragments that were used, fused to the MS2 polymerase for immunization, is shown in the diagram. These fragments were located in the $\mathrm{N}$-terminal part of the LBD (hatched box) of Rev-erbo (A83 serum), the $N$-part of the LBD of Rev-erb $\beta$ (B81 serum) and the junction between the DBD (grey box) and the hinge domain that is conserved between Rev-erb $\alpha$ and $\beta$ (AB43 serum). The T/A box and the functional domains are also indicated. (b) Characterization of the antisera directed against Rev-erb $\alpha$ and Rev-erb $\beta$ proteins. The Rev-erb $\alpha$ and Rev-erb $\beta$ cDNA were transcribed and translated in vitro using rabbit reticulocyte lysate (right-hand panel). Translated proteins were immunoprecipitated with rabbit antisera prepared against bacterially expressed peptides. The sera AB43 (left) or A83 (middle) were used to immunoprecipitate the in vitro-produced proteins, either Rev-erbo ( $\alpha$ lysate) or Rev-erb $\beta$ ( $\beta$ lysate). $\mathrm{Pi}$, serum from preimmune rabbits; Ads, serum from immunized rabbits and adsorbed against the peptide, used for immunization (MS2-AB43 for the left panel and MS2-A83 for the middle panel); I, serum from immunized rabbits; Spe, serum from immunized rabbits and adsorbed against the MS2-B81 fusion protein.

The A83 serum recognized mainly the Rev-erba protein, but weakly the Rev-erb $\beta$ protein (Fig. $1 b$, lanes 9 and 10). This was not surprising, because 
the two proteins share a high level of identical amino acids in the region used for immunization and thus probably have common epitopes. The A83 preimmune serum or the A83 serum adsorbed against the MS2-A83 protein did not recognize the hRev-erb $\alpha$ protein (Fig. $1 b$, lanes 7 and 8). In order to generate a reagent that was able to recognize Rev-erb $\alpha$, but not Rev-erb $\beta$, the A83 serum was adsorbed against the fusion protein MS2-B81. This procedure was aimed not only at neutralizing antibodies that recognized commons epitopes of MS2-A83 and MS2-B81, but also at eliminating MS2 cross-reactivity. The serum was called 'A83-specific serum' (A83 Spe) and it recognized only the Rev-erb $\alpha$ protein, and not Rev-erb $\beta$ (Fig 1b, lanes 11 and 12). Thus the A83 Spe serum specifically recognized Rev-erbo. Using the same strategy, a serum that specifically recognized Rev-erb $\beta$ but not Rev-erb $\alpha$ was also generated and called 'B81 Spe' (data not shown).

These results obtained using the in vitrotranslated Rev-erb proteins were confirmed by immunoprecipitation of lysates from COS-1 cells transfected with Rev-erb $\alpha$ or Rev-erb $\beta$ expression vectors (data not shown). These sera also were able to recognize both Rev-erb proteins present in transfected COS-1 cells using western blotting. We were also able to visualize endogenous Rev-erb proteins from a variety of human and chicken cell lines using AB43, A83 or B81 serum (not shown). We conclude that the A83 Spe and B81 Spe sera specifically recognize Rev-erb $\alpha$ and Rev-erb $\beta$, respectively, and that the $\mathrm{AB} 43$ serum recognizes the two proteins.

\section{Nuclear localization of Rev-erbo and Rev-erb $\beta$}

To examine the cellular localization of Rev-erb proteins, COS-1 cells were transfected with expression vectors for Rev-erb $\alpha$ or Rev-erb $\beta$ proteins, and their subcellular localization was assayed by immunofluorescence with the AB43 serum on fixed COS-1 cells (Fig. 2). Using this serum, we observed a specific signal in the nucleus of cells transfected with either a pSG5-Rev-erba (Fig. 2c) or a pSG5-Rev-erb $\beta$ (Fig. 2d) expression vector. No staining was visualized with the preimmune AB43 serum (Fig. 2a, and data not shown). Similarly, no staining was observed in cells transfected with the control vector pSG5
(Fig. 2b). These experiments clearly show that, in the context of transiently transfected COS-1 cells, both Rev-erb $\alpha$ and Rev-erb $\beta$ are nuclear proteins.

Because Rev-erbs are large proteins, they need an active translocation machinery that recognizes their NLS in order to enter the nucleus. To map the Rev-erba NLS, we used immunofluorescence to test the localization of several deletion mutants of Rev-erba (Fig. 3). The 1-236 deletion mutant contains the $\mathrm{A} / \mathrm{B}$ and $\mathrm{C}$ domains in addition to a small part of the hinge region, whereas the 236-614 deletion mutant contains the $\mathrm{D}$ and $\mathrm{E}$ domains (Fig. 3a). In these experiments, the wild-type Rev-erbo was localized exclusively in the nucleus in $81 \%$ of the transfected cells, and was localized in both nucleus and cytoplasm in $19 \%$ of the cells. Like the full-size protein, the 1-236 mutant was exclusively nuclear in a large majority of the cells $(70 \%)$ and was present in both nucleus and cytoplasm for the remaining 30\% (Fig. 3a, b). In contrast, the 236-614 mutant was cytoplasmic in $100 \%$ of the transfected cells (Fig. 3a, b). This finding was confirmed by the analysis of several C-terminal deletion mutants, all of which were found in the cytoplasm (Fig. 3a). This deletional mutant approach suggests that no cryptic NLS is located in the $\mathrm{E}$ domain of Rev-erba.

As the percentage of cells exhibiting exclusively nuclear staining seemed to be lower for the 1-236 mutant than for the full-size protein, and because, in many instances, the NLS of nuclear receptors is located in the $\mathrm{D}$ domain, we checked whether we might have disrupted a NLS signal by creating the different deletional mutants. To test this hypothesis, we generated another N-terminal Rev-erba mutant, the 1-288 protein, which extends further into the D domain. Like the 1-236 protein, the 1-288 mutant was exclusively nuclear in $68 \%$ of the stained cells, and localized in both nucleus and cytoplasm in $32 \%$ of the cells (Fig. 3a).

The Rev-erba gene encodes two N-terminal isoforms: the major one, Rev-erbal, is 614 amino acids long and the second one, Rev-erba2, is generated from an internal promoter and translated from an internal ATG codon located at position 107 within the A/B region of Reverbal (G. Triqueneaux et al., unpublished observations). Like Rev-erba1, the Rev-erba2 protein was predominantly nuclear when transiently 


\section{Rev-erba (piAB43)}
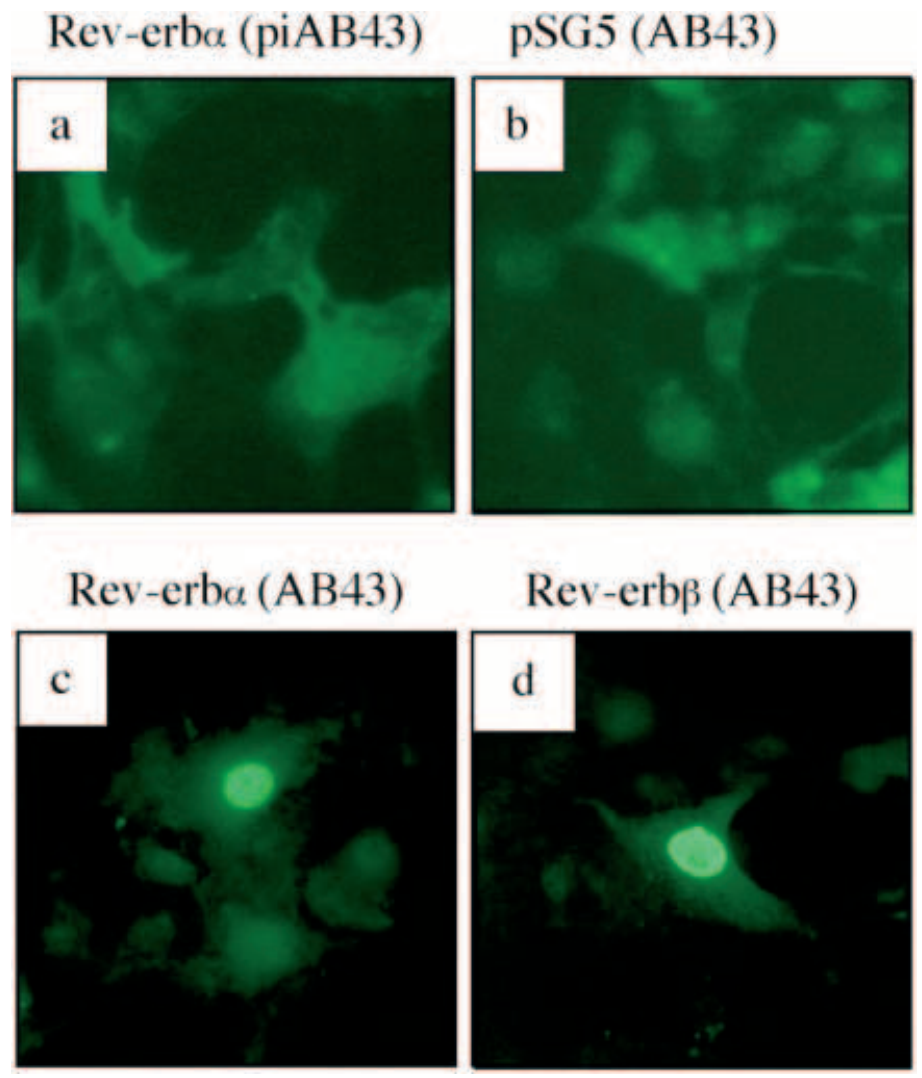

\section{Rev-erbß (AB43)}

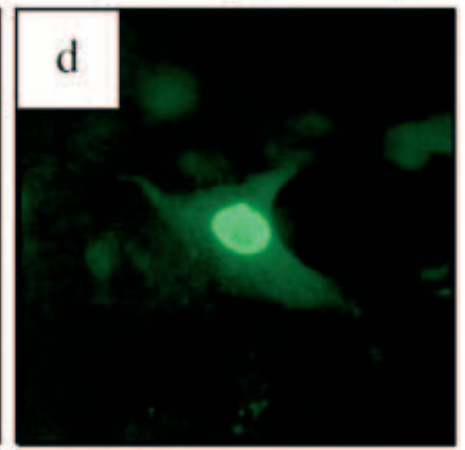

Figure 2 Subcellular localization of Rev-erb $\alpha$ and Rev-erb $\beta$. The location of the proteins was studied by immunofluorescence on transiently transfected COS-1 cells. The preimmune serum (piAB43) gives no signal on COS-1 cells transfected with a pSG5-Rev-erb $\alpha$ expression vector (a). The AB43 serum was used on COS- 1 cells transfected with the PSG5 parental vector (b), pSG5-Rev-erb $\alpha$ (c) or pSG5-Rev-erb $\beta$ (d).

transfected into COS-1 cells, suggesting that the NLS is not located within the first 107 amino acids of the Rev-erbal protein (Fig. 3a). This was further confirmed by the analysis of several N-terminal truncations of the 1-236 construct that also exhibited nuclear localization (Fig. 3a). The lower number of cells exhibiting exclusive nuclear staining in this experiment is likely to be due to the small size of mutant proteins (from 24 to $18 \mathrm{kDa}$ ), because it is known that small proteins $(<30 \mathrm{kDa})$ can pass across the nuclear membrane to the cytoplasm by simple diffusion. Taken together, these data suggest that the Rev-erbo NLS is located in the $\mathrm{N}$-terminal part of the protein between positions 107 and 236.

\section{The NLS of Rev-erb proteins is located in the C domain}

Next, we used a GFP technique in order to map precisely the NLS of Rev-erba. Indeed, tagging nuclear receptors with GFP allows direct visualization of these receptors inside the cells, without exogenous substrates or cofactors. GFP was a cytoplasmic protein in the context of transiently transfected COS-1 cells (Fig. 4a); this makes it possible to determine the precise location of the Rev-erbo region that will target GFP into the nucleus. The fusion of the 1-236 region of Rev-erbo to the C-terminal part of GFP generated a chimera (GFP/1-236) that showed a nuclear localization (Fig. 4b), confirming the results presented above. According to the nuclear 
(a)

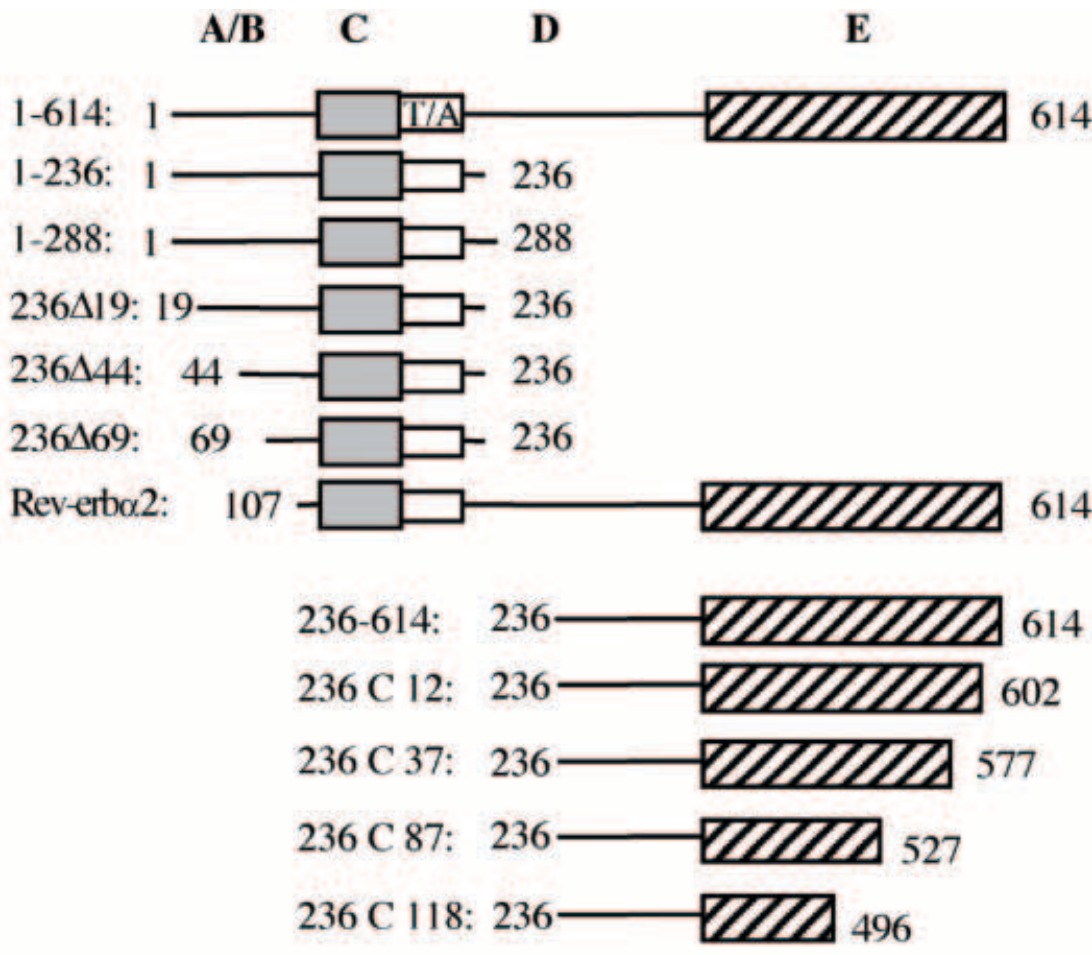

$\begin{array}{ccc}\mathrm{N} & \mathrm{C} & \mathrm{N} / \mathrm{C} \\ 81 \% & - & 19 \% \\ 70 \% & - & 30 \% \\ 68 \% & - & 32 \% \\ 60 \% & - & 40 \% \\ 57 \% & - & 43 \% \\ 56 \% & - & 44 \% \\ 85 \% & - & 15 \% \\ & & \\ - & 100 \% & - \\ - & 100 \% & - \\ - & 100 \% & - \\ - & 100 \% & - \\ - & 100 \% & -\end{array}$

(b)

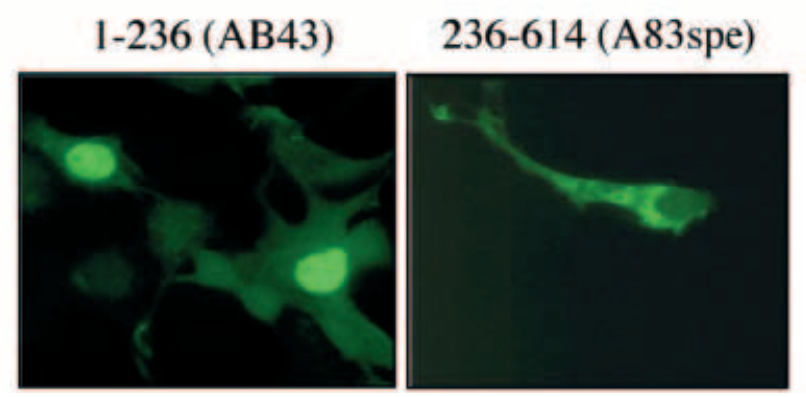

Figure 3 The major Rev-erb $\alpha$ NLS is located in the 107-236 region. (a) Structure and subcellular localization of Rev-erb $\alpha$ deletion mutants. The structure of the full-length hRev-erbo1 protein (1-614) is depicted, with its various functional domains. Grey boxes correspond to the DBD, and hatched boxes to the LBD. The T and A boxes in the hinge domain are shown. The AB43 serum (for the 1-236 construct and its derivatives) and the A83 Spe serum (for the 236-614 construct and its derivatives) were used to assay the subcellular localization of Rev-erb $\alpha$ deletion mutants and Rev-erbo2 (107-614) by immunofluorescence on transfected fixed COS-1 cells. In each case, the localization and the proportion of cells exhibiting a given subcellular localization of the protein is indicated: $\mathrm{N}$, nuclear; $\mathrm{C}$, cytoplasmic; N/C, nuclear and cytoplasmic. The 236-614 proteins and the C-terminal deletion mutants are exclusively cytoplasmic for $100 \%$ of the transfected cells. (b) The location of the proteins was studied by immunofluorescence on transiently transfected COS-1 cells. The location of the protein encoded by the pSG5-Rev-erbo1-236 (left) and pSG5-Rev-erb $\alpha 236-614$ (right) vectors was studied using the $\mathrm{AB} 43$ and $\mathrm{A} 83$ Spe antisera respectively.

localization of Rev-erba2, the GFP/1-107 chimera exhibited a nucleocytoplasmic localization (Fig. 4c), whereas the GFP/107-236 protein remained nuclear (Fig. 4d).
These results suggest that the major Rev-erb $\alpha$ NLS is located in the DBD. This region contains the $\mathrm{T}$ and $\mathrm{A}$ boxes in the $\mathrm{N}$-terminal region of the D domain (position 198-226 of hRev-erba). As 

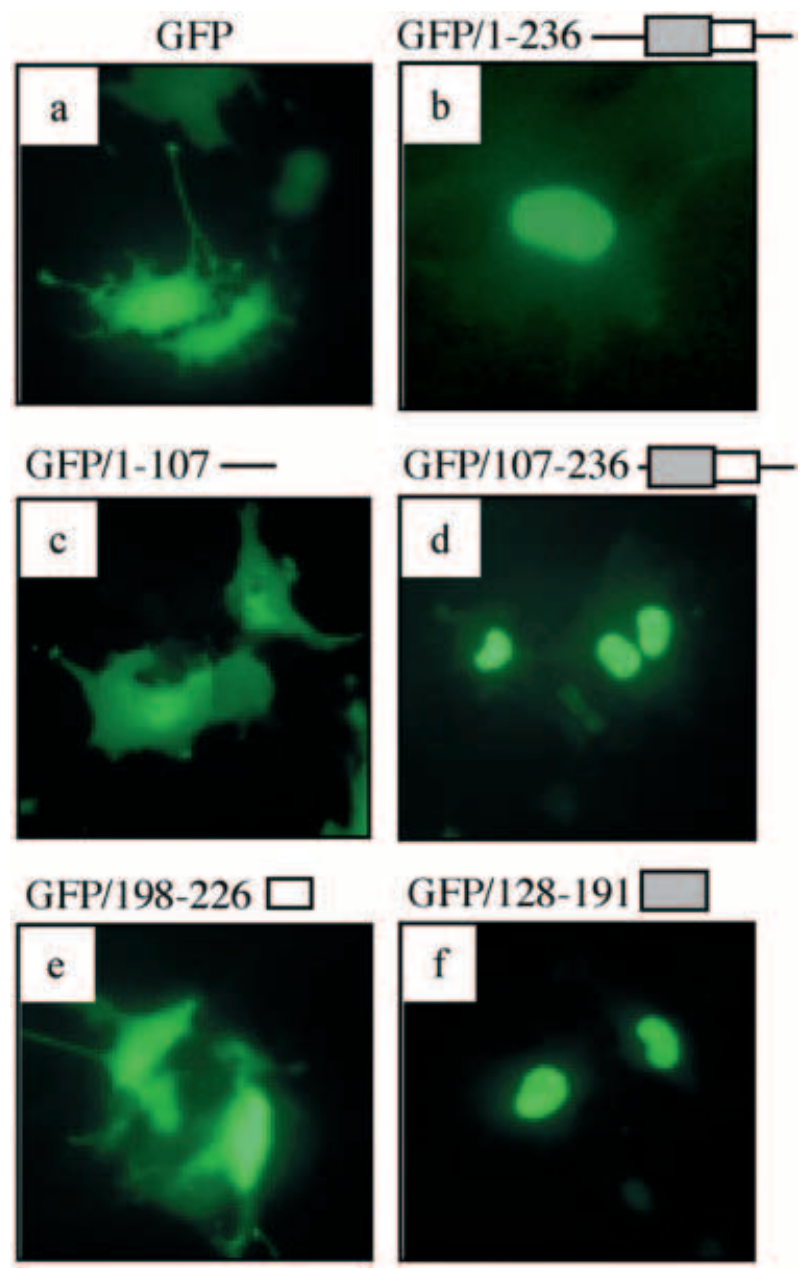

Figure 4 The Rev-erb $\alpha$ NLS is located within the zinc fingers. The subcellular localization of various GFP/Reverbo fusion proteins was studied in transiently transfected COS-1 cells. (a) GFP alone. (b-f) Different $\mathrm{N}$-terminal parts of Rev-erbo fused to GFP: 1-236 (b), 1-107 (c), 107-236 (d), 198-226 (e) and 128-191 (f). In each case the functional domains are shown schematically above the picture.

the $\mathrm{T}$ and $\mathrm{A}$ boxes of $\mathrm{TR} \beta$ and $\mathrm{AR}$ are known to contain an NLS (Zhou et al. 1994, Zhu et al. 1998), and this region of Rev-erb $\alpha$ is rich in basic amino acids that are often parts of NLSs in general (LaCasse \& Lefebvre 1995), we tested whether the $\mathrm{T}$ and $\mathrm{A}$ boxes of Rev-erb $\alpha$ could target GFP to the nucleus. Surprisingly, the GFP/198-226 chimera, which contains the $\mathrm{T}$ and $\mathrm{A}$ boxes of the hRev-erb $\alpha$ protein, exhibited a nucleocytoplasmic localization (Fig. 4e). Consistent with this observation, the GFP/128-191 mutant containing only the $\mathrm{C}$ domain with its two zinc fingers showed strong and clear nuclear staining (Fig. 4f).

\section{The location of the Rev-erb NLS in the C domain is specific}

The $\mathrm{C}$ domain of Rev-erb $\alpha$ and Rev-erb $\beta$ have $97 \%$ amino acid identity (Fig. 5a). We thus determined whether Rev-erb $\beta$ protein presents the same particular NLS location as Rev-erba. To this end, we fused the corresponding region of Rev-erb $\beta$ to GFP (GFP/DBD.Rev-erb $\beta$ ) and transfected this construct into COS-1 cells. The resulting chimera protein clearly showed a strong nuclear localization (Fig. 5b, panels a and b). Given this, we decided to test if this finding could be extended to the closely related ROR orphan receptors that exhibit 58\% amino acid identity within the $\mathrm{C}$ domain. Using the same approach, we generated GFP/DBD.ROR $\alpha$ and GFP/ DBD.ROR $\beta$ constructs that were introduced into COS-1 cells. We observed that in both cases the fusion proteins remained cytoplasmic (Fig. 5b, panels $\mathrm{c}$ and $\mathrm{d}$ ). This surprising result suggests that the location of an NLS inside the $\mathrm{G}$ domain is specific for Rev-erb $\alpha$ and Rev-erb $\beta$ proteins, and that the NLS for ROR proteins is located in other regions of the protein.

The high amino acid conservation between the $\mathrm{C}$ domain of Rev-erb and ROR proteins and the three-dimensional structure of the Rev-erba/DNA complex determined by X-ray crystallography (Zhao et al. 1998, and Fig. 5c) allowed us to predict amino acids that may be critical for this NLS, as these amino acids should be accessible residues not conserved in ROR proteins. An alignment of hRev-erb $\alpha$ and ROR amino acid sequences thus suggested that the two basic residues, Lys ${ }^{167}$ and $\mathrm{Arg}^{168}$ (A135 and A136 respectively, in the three-dimensional structure from Zhao et al. 1998), of the Rev-erba DBD and not present in ROR, could be important for interactions with the nuclear transport machinery. As shown in Fig. 5c, these two polar residues are localized in the loop region linking the two zinc finger domains, which is well exposed at the monomer protein surface.

In order to test this assumption, the two putative residues of the Rev-erba DBD were substituted with their ROR $\alpha$ counterparts (see alignment in Fig. 5a). The introduction of the resulting GFP fusion protein, GFP/DBDm. Rev-erba $(* \mathrm{~S})$, in COS-1 cells clearly demonstrated the importance 
(a)

hRev-erb $\alpha$

ckRev-erb $\beta$

hROR $\alpha(60 \%)$

ckROR $\beta$

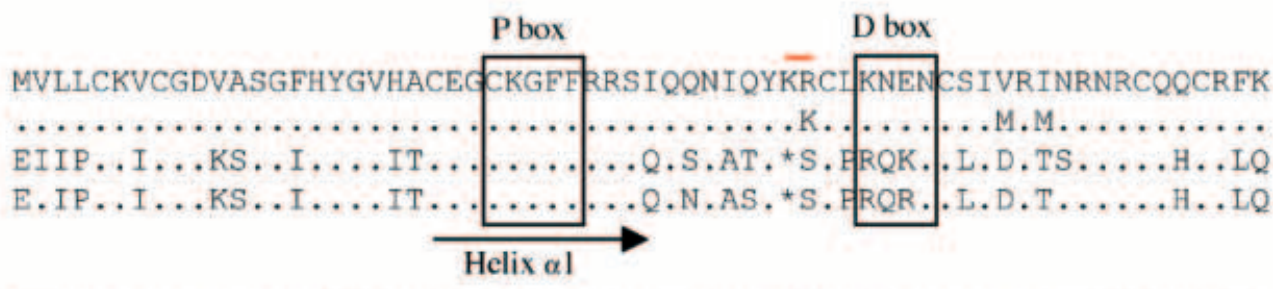

DBDm.Rev-erb $\alpha(* \mathrm{*})$

DBDm.ROR $\alpha$ (KR)

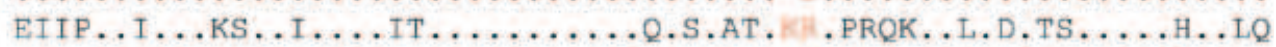

(b)

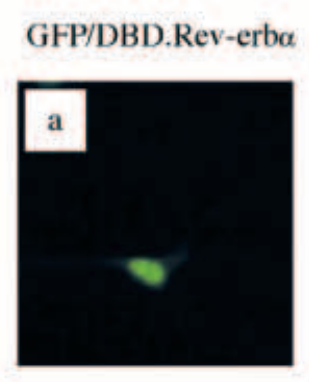

GFP/DBD.Rev-erb $\beta$

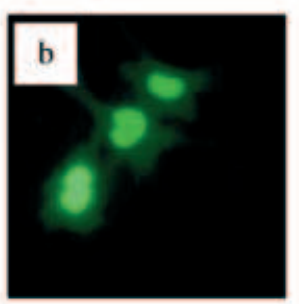

GFP/DBD.ROR $\alpha$
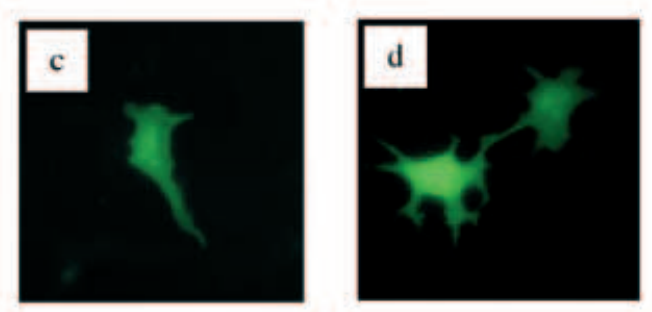

GFP/DBDm.Rev-erbo $\left({ }^{*} \mathrm{~S}\right)$

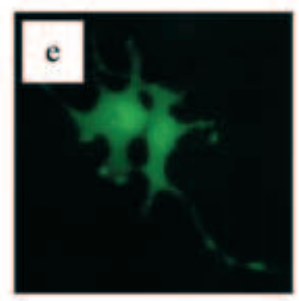

GFP/DBDm.ROR $\alpha(K R)$

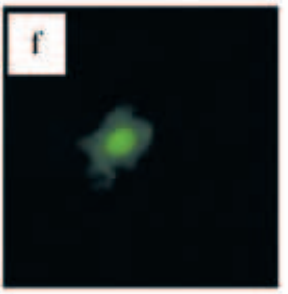

(c)

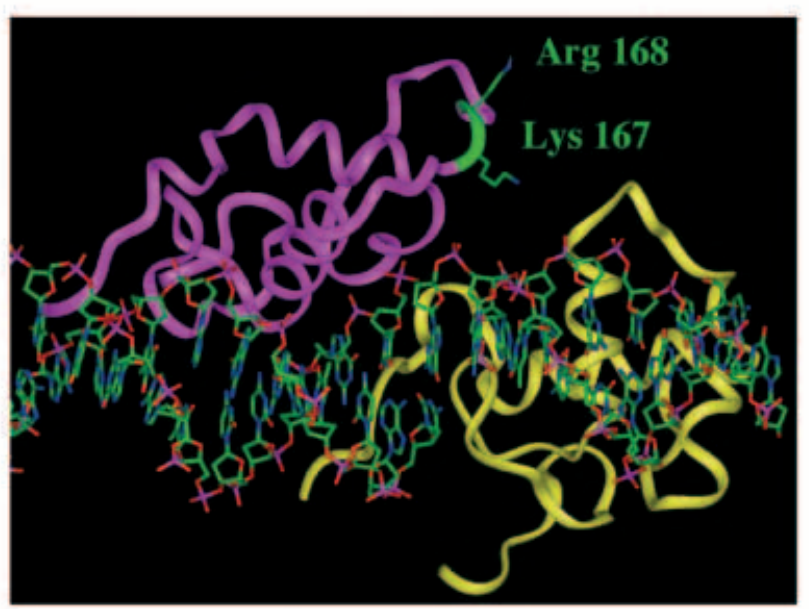


of these two polar residues, because their mutation impaired the nuclear localization of the GFP/ DBD.Rev-erba fusion protein (Fig. 5b, panel e). Introduction of the two basic amino acids K167 and R168 from Rev-erb $\alpha$ into an ROR $\alpha$ DBD, DBDm.ROR $\alpha(\mathrm{KR})$, rendered this domain able to target GFP protein into the nucleus (Fig. 5b, panel f), showing that these two amino acids were sufficient for nuclear targeting. These striking data demonstrate that residues K167 and R168 are critical structural determinants for Rev-erb protein targeting to the nucleus.

\section{Discussion}

In the present report we examined the subcellular localization of Rev-erb proteins. Our results, obtained in immunofluorescence studies, demonstrate that both Rev-erb $\alpha$ and Rev-erb $\beta$ were nuclear in transfected COS-1 cells. The GFP fusion protein technique allowed us to demonstrate that the major NLS of Rev-erb $\alpha$ and Rev-erb $\beta$ is in the DBD and, more precisely, in the zinc finger region, and unlike other nuclear receptors, no NLS is present within the LBD. The corresponding regions of $\operatorname{ROR} \alpha$ and $\operatorname{ROR} \beta$ do not contain such NLSs. The structural comparison between Reverb $\alpha$ and ROR $\alpha$ in this region identified two residues, $\mathrm{K} 167$ and $\mathrm{R} 168$, that are critical for the nuclear localization of Rev-erba. Strikingly, the introduction of these two residues in the ROR $\alpha$ DBD in the context of a GFP fusion protein allowed this protein to enter the nucleus.

The absence of any NLS in the Rev-erb $\mathrm{E}$ domain is surprising, given that many liganded receptors such as GR and ER $\alpha$ have an NLS in this region (Picard \& Yamamoto 1987, Ylikomi et al. 1992). We are confident that the cytoplasmic localization of the 236-614 mutant is not an artefact, because a comparable result was also found with a series of C-terminal deletions of this domain. As the subcellular location of the 236-614 protein was studied with a different serum (namely A83) than AB43 and was able to recognize the Rev-erb $\alpha$ N-terminal region, one might argue that the A83 serum may be unable to detect proteins in the nucleus. However, with both the A83 Spe serum and AB43 serum, we consistently observed a nuclear localization of the full-length Rev-erba protein, with identical proportions between nuclear and cytoplasmic labelling (data not shown). Hence, the A83 Spe serum is able to enter the nucleus and to recognize the Rev-erbo protein in this environment. Interestingly, the NLSs that have been found in the LBD of nuclear receptors have, to date, been described only for liganded receptors, such as GR and ER $\alpha$, and have been found to be ligand-dependent (Picard \& Yamamoto 1987, Ylikomi et al. 1992). It seems that these NLSs are hidden and not available for the nuclear transport complex in the apo-form of the receptor. As ligand binding promotes a conformational change in the LBD of these receptors, one might expect that, upon such changes, the LBD - and NLS - are thus exposed and available for nuclear transport. Because modelling of the three-dimensional structure of the Rev-erba LBD suggests that this receptor is a true orphan with no available ligand binding pocket (Renaud et al. 2000), we cannot exclude the possibility that the LBD includes a cryptic NLS that is never exposed to the nuclear transport apparatus. Nevertheless, the fact that several C-terminal mutants of the Rev-erba LBD remain in the cytoplasm argues against such a possibility.

Nuclear localization signals have been mapped in the region encompassing the $\mathrm{T}$ and $\mathrm{A}$ boxes of numerous liganded receptors such as GR, TR $\alpha$, TR $\beta$, AR, ER and PR (Picard \& Yamamoto 1987, Guiochon-Mantel et al. 1989, Ylikomi et al. 1992,

Figure 5 The Rev-erb NLS is not conserved in ROR. (a) Sequence alignments of the DBD of Rev-erbo, Rev-erb $\beta$, ROR $\alpha$ and ROR $\beta$. The boxes represent the P-box and the D-box and the arrow represents the $\alpha 1$ helix. The two basic amino acids that are part of the NLS are indicated by a red bar above the Rev-erbo sequence. Asterisks $\left({ }^{*}\right)$ indicates gaps. (b) Subcellular localization of GFP/DBD chimeras: (a) DBD.Rev-erbo; (b) DBD.Rev-erbß; (c) DBD.ROR $\alpha$; (d) DBD.ROR $\beta$; (e) DBDm.Rev-erb $\alpha\left({ }^{*}\right.$ S) in which the K167, R168 positions were mutated toward the ${ }^{*} S$ found in ROR $\alpha$ (where * is a gap); (f) DBDm.ROR $\alpha(K R)$ in which the *S position of ROR $\alpha$ was mutated toward the $\mathrm{K}$ and $\mathrm{R}$ found in Rev-erb $\alpha$. (c) Representation of the three-dimensional structure of the Rev-erb $\alpha$ orphan nuclear receptor bound to its RevDR2 DNA target as a homodimer (accessible at Protein Data Bank under reference code 1a6y; Zhao et al. 1998). The protein backbone is shown as a pink ribbon. Side chains of the two mutated basic residues Lys ${ }^{167}$ and Arg $^{168}$ (A135 and A136, respectively, in Zhao et al. 1998), which are crucial for the NLS of Rev-erb proteins, are displayed. 
hRev-erb $\alpha$ (NR1D1) MVLLCKVCGDVASGFHYGVHACEGCKGF FRRSIQQNIQ * * YKRCLKNENCS IVR INRNRCQQCRFK hRev-erb $\beta$ (NR1D2)

drE75 (NR1D3)
drE78 (NR1E1)
hROR $\alpha$ (NR1F1)
hROR $\beta$ (NR1F2)
hROR $\gamma$ (NRIF3)
drHR3 (NR1F4)
hPPAR $\alpha$ (NR1C1)
hPPAR $\beta$ (NR1C2)
hPPAR $\gamma$ (NR1C3)
hTR $\alpha$ (NR1A1)
hTR $\beta$ (NR1A2)
hRAR $\alpha$ (NR1B1)
hRAR $\beta$ (NR1B2)
hRAR $\gamma$ (NR1B3)
hSF1 (NR5A1)
hTR2 (NR2C1)

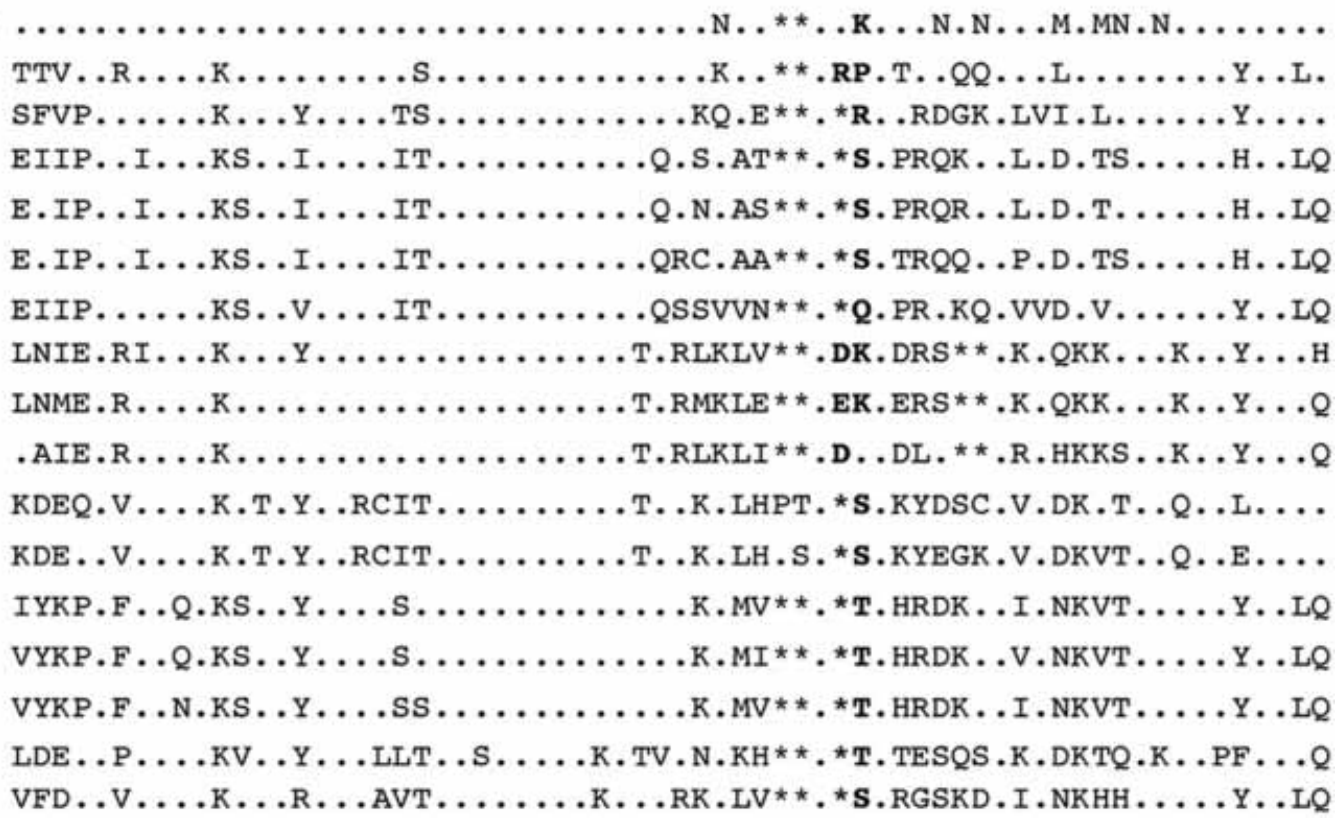

Figure 6 Alignment of the DBD of several nuclear receptors. This alignment shows that the basic character of the region upstream of the D-box is not conserved in all the superfamily members. Asterisks $\left(^{*}\right)$ indicates gaps.

Accession numbers of the corresponding sequences can be found in Laudet \& Gronemeyer (2002). The official nomenclature of each receptor (Nuclear Receptors Nomenclature Committee 1999) is indicated.

Lee \& Mahdavi 1993, Zhou et al. 1994, Zhu et al. 1998). The corresponding region of Rev-erba, when fused to GFP, did not target the fusion protein to the nucleus. This suggests that the NLS of Rev-erb proteins is not in this region. Further experiments revealed that the NLS of Rev-erb is located in the zinc finger region. For the closely related ROR orphan receptors, the NLSs do not locate in the same region, but can be found there in two other unrelated orphan receptors, TR2 (NR2C1) and SF-1 (NR5A1) (Yu et al. 1998, Hammer et al. 1999). In fact, it has been shown that in $75 \%$ of known transcription factors, the NLS is located within or near (10 amino acids around) the DBD (Hager et al. 2000, Laudet \& Gronemeyer 2002). For example, the transcription factor ETS-1 or the homeobox protein PDX-1 have their NLS in their DBD (Boulukos et al. 1989, Hessabi et al. 1999). The proximity of these two functions appears to be independent of both the type of DBD (zinc fingers, homeodomain, helix-loop-helix, etc.) and the type of NLS. Thus the situation observed for Rev-erb and for at least two other orphan receptors, TR2 and SF-1, could be the rule rather than the exception. Indeed, the fact that the NLSs of nuclear receptors often include the $\mathrm{T}$ and $\mathrm{A}$ boxes, which play an important part in DNA binding, supports this notion. It is conceivable that the location of the NLS outside the DBD, which was observed for liganded receptors such as GR and $\mathrm{ER} \alpha$, may be linked to ligand-dependent nuclear localization, which induces an unmasking of a cryptic NLS function. Interestingly, the DBD has recently been shown to contain a nuclear export signal, which is conserved between most nuclear receptors (Tyagi et al. 1998, Black et al. 2001).

One remarkable observation of our study is that the mutation of only two amino acids within the ROR $\alpha$ DBD can induce a nuclear translocation of this domain fused to the GFP protein. In general, two amino acids are not sufficient to establish an independent NLS (LaCasse \& Lefebvre 1995). This suggests that a proto-NLS exists in this region of ROR and that the addition of two basic amino acids is sufficient to reveal this function. Comparison of Rev-erb and ROR DBD indicates two structurally different regions: (i) the first zinc finger loop (positions 134-148 in hRev-erba), and (ii) between the end of $\alpha 1$ helix and the D box in 
hRev-erba (Fig. 5a). Of these two regions, only that between the end of $\alpha 1$ helix and the $\mathrm{D}$ box contains basic amino acids $\left(\mathrm{Lys}^{167}\right.$ and $\mathrm{Arg}^{168}$ in the Rev-erb $\alpha$ protein). Moreover, Rev-erb $\alpha$ DBD crystallography showed that this region (Lys-Arg for Rev-erb $\alpha$ and Lys-Lys for Rev-erb $\beta$ ) is exposed and hence accessible to other proteins (Zhao et al. 1998, and Fig. 5c). This suggests that, in Rev-erb proteins and possibly in ROR proteins, the conformation of this region is favourable for an interaction with the nuclear transport complex, and that it is only the interaction surface itself that is different between the two proteins.

The NLS that we mapped within the Rev-erb proteins contains two critical basic amino acids. This suggests that the basic character of these residues is important and that this NLS could be related to classical basic NLS sequences, such as the one found in the SV40 T protein. These two critical and necessary basic amino acids could function as part of a bipartite NLS that may also contain the conserved pair of basic amino acids, RR, located just downstream of the P-box. Strikingly, these two amino acids are part of a conserved nuclear export signal that has been mapped by Black et al. (2001) in several nuclear receptors (sequence FFK/RR). It would be interesting to study in more detail the importance of the neighbouring residues for the nuclear localization of Rev-erb proteins. The sequence alignment between Rev-erb and other nuclear receptors indicates that the region, which contains the two basic amino acids in Rev-erba and Rev-erb $\beta$, includes only one basic residue in the Drosophila homologue E75 and in the distantly related peroxisome proliferator-activated receptors (NR1G). The SF1 and TR2 orphan nuclear receptors, which also contain an NLS in their DBD, do not have any basic amino acid in this region, suggesting that their NLS is located elsewere (Fig. 6). The NLS of TR2 is located within the 20 N-terminal amino acids of the DBD (KDGVINKHHRNRGQYGRLQR) and thus does not overlap the region we detected in Rev-erb proteins. In many cases, receptors that we have checked have a gap in this region. The sequence analysis thus suggests that the position of the Rev-erb $\alpha$ NLS is probably strictly specific to the Rev-erb proteins.

Rev-erb proteins are interesting members of the nuclear receptor superfamily because they do not have identified ligands, have a truncated AF2 domain, and repress transcription when bound to DNA as monomers or dimers. In addition, Rev-erb $\alpha$ protein is implicated in at least two principal functions: control of liver metabolism and circadian rhythms. Here, we demonstrate that this group of orphan receptors presents an unusual and specific NLS in their DBD. Further experiments will determine more precisely both the role of Rev-erb proteins in metabolic pathways and circadian rhythms, and whether there are possible implications of this particular NLS in regulation of these different functions.

\section{Acknowledgements}

We thank Gerard Triqueneaux, Alain Sergeant and Michael Schubert for help and critical reading of the manuscript. S T holds a fellowship from ARC. We thank CNRS, MENRT (ACI programs), $\mathrm{ARC}$ and Région Rhône-Alpes for financial support.

\section{References}

Adelmant G, Begue A, Stehelin D \& Laudet V 1996 A functional Rev-erb alpha responsive element located in the human Rev-erb alpha promoter mediates a repressing activity. PNAS $\mathbf{9 3}$ 3553-3558.

Balsalobre A, Damiola F \& Schibler U 1998 A serum shock induces circadian gene expression in mammalian tissue culture cells. Cell 93 929-937.

Black BE, Holaska JM, Rastinejad F \& Paschal BM 2001 DNA binding domains in diverse nuclear receptors function as nuclear export signals. Current Biology 11 1749-1758.

Bonnelye E, Vanacker JM, Desbiens X, Begue A, Stehelin D \& Laudet V 1994 Rev-erb beta, a new member of the nuclear receptor superfamily, is expressed in the nervous system during chicken development. Cell Growth and Differentiation 5 1357-1365.

Boulukos KE, Pognonec P, Rabault B, Begue A \& Ghysdael J 1989 Definition of an Etsl protein domain required for nuclear localization in cells and DNA-binding activity in vitro. Molecular and Cellular Biology 9 5718-5721.

Carlberg C, Hooft van Huijsduijnen R, Staple JK, DeLamarter JF \& Becker-Andre M 1994 RZRs, a new family of retinoid-related orphan receptors that function as both monomers and homodimers. Molecular Endocrinology 8 757-770.

Chawla A \& Lazar MA 1993 Induction of Rev-ErbA alpha, an orphan receptor encoded on the opposite strand of the alphathyroid hormone receptor gene, during adipocyte differentiation. Journal of Biological Chemistry 268 16265-16269.

Delaunay F, Thisse C, Marchand O, Laudet V \& Thisse B 2000 An inherited functional circadian clock in zebrafish embryos. Science 289 297-300.

Downes M, Carozzi AJ \& Muscat GE 1995 Constitutive expression of the orphan receptor, Rev-erbA alpha, inhibits muscle differentiation and abrogates the expression of the myoD gene family. Molecular Endocrinology 9 1666-1678. 
Dumas B, Harding HP, Choi HS, Lehmann KA, Chung M, Lazar MA \& Moore DD 1994 A new orphan member of the nuclear hormone receptor superfamily closely related to Rev-Erb. Molecular Endocrinology 8 996-1005.

Enmark E \& Gustafsson JA 1996 Orphan nuclear receptors - the first eight years. Molecular Endocrinology 10 1293-1307.

Enmark E, Kainu T, Pelto-Huikko M \& Gustafsson JA 1994 Identification of a novel member of the nuclear receptor superfamily which is closely related to Rev-ErbA. Biochemical and Biophysical Research Communications 204 49-56.

Escriva H, Delaunay F \& Laudet V 2000 Ligand binding and nuclear receptor evolution. Bioessays 22 717-727.

Fejes-Toth G, Pearce D \& Naray-Fejes-Toth A 1998 Subcellular localization of mineralocorticoid receptors in living cells: effects of receptor agonists and antagonists. PNAS 95 2973-2978.

Georget V, Terouanne B, Lumbroso S, Nicolas JC \& Sultan C 1998 Trafficking of androgen receptor mutants fused to green fluorescent protein: a new investigation of partial androgen insensitivity syndrome. Fournal of Clinical Endocrinology and Metabolism 83 3597-3603.

Gervois P, Chopin-Delannoy S, Fadel A, Dubois G, Kosykh V, Fruchart JC, Najib J, Laudet V \& Staels B 1999 Fibrates increase human REV-ERBalpha expression in liver via a novel peroxisome proliferator-activated receptor response element. Molecular Endocrinology 13 400-409.

Giguere V, Tini M, Flock G, Ong E, Evans RM \& Otulakowski G 1994 Isoform-specific amino-terminal domains dictate DNAbinding properties of ROR alpha, a novel family of orphan hormone nuclear receptors. Genes and Development 8 538-553.

Guiochon-Mantel A, Loosfelt H, Lescop P, Sar S, Atger M, Perrot-Applanat M \& Milgrom E 1989 Mechanisms of nuclear localization of the progesterone receptor: evidence for interaction between monomers. Cell 57 1147-1154.

Guiochon-Mantel A, Lescop P, Christin-Maitre S, Loosfelt H, Perrot-Applanat M \& Milgrom E 1991 Nucleocytoplasmic shuttling of the progesterone receptor. EMBO $7 \mathbf{1 0} 3851-3859$

Hager GL, Lim CS, Elbi C \& Baumann CT 2000 Trafficking of nuclear receptors in living cells. Fournal of Steroid Biochemistry and Molecular Biology 74 249-254.

Hammer GD, Krylova I, Zhang Y, Darimont BD, Simpson K, Weigel NL \& Ingraham HA 1999 Phosphorylation of the nuclear receptor SF-1 modulates cofactor recruitment: integration of hormone signaling in reproduction and stress. Molecular Cell $\mathbf{3}$ 521-526.

Harding HP \& Lazar MA 1995 The monomer-binding orphan receptor Rev-Erb represses transcription as a dimer on a novel direct repeat. Molecular and Cellular Biology 15 4791-4802.

Hessabi B, Ziegler P, Schmidt I, Hessabi C \& Walther R 1999 The nuclear localization signal (NLS) of PDX-1 is part of the homeodomain and represents a novel type of NLS. European Fournal of Biochemistry 263 170-177.

Hirose T, Smith RJ \& Jetten AM 1994 ROR gamma: the third member of ROR/RZR orphan receptor subfamily that is highly expressed in skeletal muscle. Biochemical and Biophysical Research Communications 205 1976-1983.

Htun H, Barsony J, Renyi I, Gould DL \& Hager GL 1996 Visualization of glucocorticoid receptor translocation and intranuclear organization in living cells with a green fluorescent protein chimera. PNAS 93 4845-4850.

Kassam A, Capone JP \& Rachubinski RA 1999 Orphan nuclear hormone receptor RevErbalpha modulates expression from the promoter of the hydratase-dehydrogenase gene by inhibiting peroxisome proliferator-activated receptor alpha-dependent transactivation. Fournal of Biological Chemistry 274 22895-22900.

Koelle MR, Segraves WA \& Hogness DS 1992 DHR3: a Drosophila steroid receptor homolog. PNAS $\mathbf{8 9} 6167-6171$.
LaCasse EC \& Lefebvre YA 1995 Nuclear localization signals overlap DNA- or RNA-binding domains in nucleic acid-binding proteins. Nucleic Acids Research 23 1647-1656.

Laudet V 1997 Evolution of the nuclear receptor superfamily: early diversification from an ancestral orphan receptor. Fournal of Molecular Endocrinology 19 207-226.

Laudet V \& Gronemeyer H 2002 The Nuclear Receptors - Facts Book. San Diego, San Francisco, New York, Boston, London, Sydney, Tokyo: Academic Press.

Laudet V, Begue A, Henry-Duthoit C, Joubel A, Martin P, Stehelin D \& Saule S 1991 Genomic organization of the human thyroid hormone receptor alpha (c-erbA-1) gene. Nucleic Acids Research 19 $1105-1112$

Lazar MA, Hodin RA, Darling DS \& Chin WW 1989 A novel member of the thyroid/steroid hormone receptor family is encoded by the opposite strand of the rat c-erbA alpha transcriptional unit. Molecular and Cellular Biology 9 $1128-1136$

Lee C, Etchegaray JP, Cagampang FR, Loudon AS \& Reppert SM 2001 Posttranslational mechanisms regulate the mammalian circadian clock. Cell 107 855-867.

Lee Y \& Mahdavi V 1993 The D domain of the thyroid hormone receptor alpha 1 specifies positive and negative transcriptional regulation functions. Fournal of Biological Chemistry $2682021-$ 2028.

Lim CS, Baumann CT, Htun H, Xian W, Irie M, Smith CL \& Hager GL 1999 Differential localization and activity of the $\mathrm{A}$ - and B-forms of the human progesterone receptor using green fluorescent protein chimeras. Molecular Endocrinology 13 366-375.

Madan AP \& DeFranco DB 1993 Bidirectional transport of glucocorticoid receptors across the nuclear envelope. PNAS 90 3588-3592.

Mangelsdorf DJ, Thummel C, Beato M, Herrlich P, Schutz G, Umesono K, Blumberg B, Kastner P, Mark M, Chambon P, et al. 1995 The nuclear receptor superfamily: the second decade. Cell 83 835-839.

Miyajima N, Horiuchi R, Shibuya Y, Fukushige S, Matsubara K, Toyoshima K \& Yamamoto T 1989 Two erbA homologs encoding proteins with different T3 binding capacities are transcribed from opposite DNA strands of the same genetic locus. Cell 57 31-39.

Nuclear Receptors Nomenclature Committee 1999 A unified nomenclature system for the nuclear receptor superfamily. Cell $\mathbf{9 7}$ $161-163$

Picard D \& Yamamoto KR 1987 Two signals mediate hormonedependent nuclear localization of the glucocorticoid receptor. EMBO $763333-3340$.

Renaud JP, Harris JM, Downes M, Burke LJ \& Muscat GE 2000 Structure-function analysis of the Rev-erbA and RVR ligand-binding domains reveals a large hydrophobic surface that mediates corepressor binding and a ligand cavity occupied by side chains. Molecular Endocrinology 14 700-717.

Retnakaran R, Flock G \& Giguere V 1994 Identification of RVR, a novel orphan nuclear receptor that acts as a negative transcriptional regulator. Molecular Endocrinology 8 1234-1244.

Segraves WA \& Hogness DS 1990 The E75 ecdysone-inducible gene responsible for the 75B early puff in Drosophila encodes two new members of the steroid receptor superfamily. Genes and Development $4204-219$.

Tyagi RK, Amazit L, Lescop P, Milgrom E \& Guiochon-Mantel A 1998 Mechanisms of progesterone receptor export from nuclei: role of nuclear localization signal, nuclear export signal, and ran guanosine triphosphate. Molecular Endocrinology 12 $1684-1695$.

Vu-Dac N, Chopin-Delannoy S, Gervois P, Bonnelye E, Martin G, Fruchart JC, Laudet V \& Staels B 1998 The nuclear receptors 
peroxisome proliferator-activated receptor alpha and Rev-erbalpha mediate the species-specific regulation of apolipoprotein A-I expression by fibrates. Fournal of Biological Chemistry 273 25713-25720.

Ylikomi T, Bocquel MT, Berry M, Gronemeyer H \& Chambon P 1992 Cooperation of proto-signals for nuclear accumulation of estrogen and progesterone receptors. EMBO F 11 3681-3694.

Yu Z, Lee CH, Chinpaisal C \& Wei LN 1998 A constitutive nuclear localization signal from the second zinc-finger of orphan nuclear receptor TR2. Fournal of Endocrinology 159 53-60.

Zhao Q, Khorasanizadeh S, Miyoshi Y, Lazar MA \& Rastinejad F 1998 Structural elements of an orphan nuclear receptor-DNA complex. Molecular Cell 1 849-861.
Zhou ZX, Sar M, Simental JA, Lane MV \& Wilson EM 1994 A ligand-dependent bipartite nuclear targeting signal in the human androgen receptor. Requirement for the DNA-binding domain and modulation by NH2-terminal and carboxyl-terminal sequences. Fournal of Biological Chemistry 269 13115-13123.

Zhu XG, Hanover JA, Hager GL \& Cheng SY 1998 Hormoneinduced translocation of thyroid hormone receptors in living cells visualized using a receptor green fluorescent protein chimera. Fournal of Biological Chemistry 273 27058-27063.

Received in final form 16 October 2002 Accepted 22 October 2002 